\title{
Celtic FC's 1967 Lisbon Lions: Why the first club from Britain to win the European Cup was a defining moment for the Irish diaspora in Scotland
}

\author{
Dr John Kelly, University of Edinburgh (Scotland) \\ Dr Joseph Bradley, University of Stirling (Scotland)
}

On the $25^{\text {th }}$ May 1967 in the Portuguese capital Lisbon, Celtic Football Club defeated the Italians Internazionale from Milan 2-1 to become the first club from Britain to win the European Cup. The competition for the Champions of Europe's football leagues began in 1955. Until 1967 only four clubs from Spain, Italy and Portugal had succeeded in winning it. By 2018 barely twenty-two clubs had managed to win the continent's most prestigious football trophy. Celtic's win capped an unprecedented season in which, a club formed and sustained mainly by large sections of the Irish diaspora in Scotland, won every competition it entered. Yet, from such unprecedented and ultimately iconic sporting greatness this Celtic 'story' originated from more modest and humble beginnings. Celtic's eleven players were all born in Scotland. Ten of them were raised within twelve miles of Celtic's stadium in the east end of Glasgow (the other player coming from only thirty miles away). All Celtic's players came from workingclass $^{1}$, labouring and semi-skilled backgrounds, with several originating from areas classified today in Scotland as 'deprived' (SIDS - Scottish Index of Multiple Deprivation). Celtic’s side cost $£ 42,000$ to assemble: only two players being transferred during manager Jock Stein’s time (for $£ 30,000$ and $£ 12,000$ respectively). The 'Lisbon Lions' as they became known is widely considered the greatest team in the club's history. In the final they defeated the Italian masters of the effective ultra-defensive 'Catenaccio' system with their own trademark attacking cavalier football. All Lisbon Lions progressed through typical school and youth football teams during a period preceding modern 'Soccer Academies'.

Despite Celtic's win being reported widely and documented regularly through the years, we contend that the overwhelming majority of such discourse has considerably overlooked the magnitude of the socio-cultural significance of the event. Most of the relevant commentary is limited to recording various 'football' reference points. For example, McNee's best-selling, club sanctioned, official history of 1978 
(90 years since foundation) $)^{2}$ notes 15,000 supporters, mainly from Scotland, travelled to watch their team in the final. He records other related facts and statistics, including a passing comment on how so many of the Celtic support attended the celebration of Catholic Mass on the day of the final. ${ }^{3}$ He mentions that an accordion band and 60,000 fans welcomed Celtic back to Celtic Park with the trophy - after 200,000 had lined the streets on the team's bus journey to the stadium. The rest of McNee's story is typically journalistic and mainly concerns the game itself and wider celebrations. Apart from the reference to Catholic Celtic supporters attending Mass little of this account distinguishes Celtic's win from those of Manchester United, Nottingham Forrest, Aston Villa or Liverpool within the following decades. Similarly, Graham McColl's ${ }^{4}$ official biography is largely written in a tabloid newspaper style, noting players' thoughts and impressions, personal stories and memories of events: the journey to become winners and the final in Lisbon are accounted for with little reference to the overall social and cultural significance of the win. Campbell and Woods' often excellent narrative of Celtic Football Club's one hundred years centenary celebration $(1887 / 88)^{5}$ recognises the club and its supporters' Catholic and Irish distinctiveness. However, in what is widely considered to be the definitive historical publication on Celtic Football Club, the European Cup Final in Lisbon is confined to just a few pages reporting the game itself: again the deep and profound impact this victory represents for many Celtic supporters - in ethnic, religious and diasporic terms - is conspicuous by its absence.

In the months after the victory Scottish journalist Ian Peebles wrote the bestselling book, 'Celtic Triumphant'. ${ }^{6}$ His first words refer to 'the Scots' as being 'intensely patriotic' before adding 'yet, in sport, we usually recognise our limitations'? Representing this as a Scottish victory - accompanied by the self-proclaimed humility to recognise 'Scottish' limitations ${ }^{8}$ - he adds:

We will admit, for instance, that we are unlikely to produce the next World heavyweight champion....until less than a year ago we would also have been prepared to concede that football's greatest club prize, the European Cup, was also beyond us...... [In Lisbon] we Scots were guilty of underestimating our potential. $^{9}$

Peebles' rhetorical framing of Scotland (and Scots) as being unlikely to produce world class sporting champions works as a device to magnify his following point that:

No matter how much one may try to look at this achievement dispassionately, it would be unfair to dismiss it as anything less than absolutely fantastic. What 
else can you say about a team that won the toughest competition of all at their first attempt..... the first British side to win the European Cup. (Our emphasis)

Peebles' account of Celtic's European Cup win is justifiably described as 'absolutely fantastic' but the rich socio-cultural significance is reduced to a 'Scottish victory' and 'the first British side' to win the European Cup. Articulations such as these combine to offer an acutely superficial account when one intimately explores Celtic's win: especially in terms of its relationship to wider social, ethnic, religious, cultural and political factors in, and in relation to, Scotland. Peebles asks rhetorically, 'what else can you say about a team' from Scotland that won the European Cup? We suggest more than has currently been said (or written). When CLR James famously asked "what do they know of cricket who only cricket know?"10 he was of course imploring us to irrevocably connect the sporting realm with the social (economic, cultural, political and historical) conditions in which the sport formed and developed. From the embers of colonialism, mass starvation, revolution and rebellion in Ireland flickered the flame of an Irish diaspora negotiating and forming its identity in Scotland: and from 1888 to today Celtic Football Club has been one of their most revered totems.

This work examines the multi-faceted nature of Celtic's European Cup win by contextualising its wider historical context in order to more fully acknowledge the non-football enormity of this iconic sporting achievement. Only in this way can it be fully appreciated and understood, and the socio-cultural significance of football (and sport) be illustrated in ways which reveal the power of football (sport) to carry the hopes and dreams of imagined communities of a diaspora. ${ }^{11}$ In what follows, we chart the origins of Celtic Football Club, illustrating the intimate historical and political contexts of the club rooted in Irish migration, starvation and British colonialism. The club's Catholic and charitable origins and identities are briefly presented to contextualise the significance of the club and its evolution to the wider Irish diaspora experience in Scotland. We then illustrate how elements of Celtic and Irishness in Scotland have been Othered, treated with suspicion and hostility. Importantly, we highlight how such Othering is not unique to Irish diasporic people in Britain. We urge those concerned with tackling ethno-religious prejudice in Scotland to avoid dysconscious and subtle Othering in the name of tackling so-called sectarianism. The final section considers the Lisbon 1967 victory as an iconic moment of selfrecognition and celebration for the Irish diaspora in Scotland. Ironically, we contend 
that this was partly linked to the occasion being represented as a Scottish and British victory, enabling the previously viewed Outsiders to celebrate an identity that was within permissible boundaries of identification in Scotland.

\section{Celtic Football Club: A Socio-Historic Overview}

\section{Hunger and Starvation}

The starting point for locating Celtic's origins is the cataclysmic mass death dealing Great Starvation $^{12}$ (An Gorta Mor) in Ireland, when millions of people died or were forced to flee what was at the time a British ruled island. Irish immigration to North America and Britain increased to extraordinary levels. As one of the nearest accessible countries with a tradition of providing employment due to its often vigorous British imperialist economy, Scotland became a noteworthy site for Great Hunger and postGreat Hunger refugees and immigrants. Most of these Irish men and women were Catholic. ${ }^{13}$ Thousands of Catholics have migrated from Lithuania, Poland and Italy, but the vast majority of Catholics in Scotland, mostly located in the country's west-central belt, are either ethnically Irish or a significant element of their familial and cultural background is Irish. Largely due to An Gorta Mor refugees the number of Catholics in mid-nineteenth century Scotland rose from around 50,000 at the onset of the devastation to 150,000 by 1850 and 332,000 in 1878 (750,000 by the new millennium). An Gorta Mor was to irrevocably change the nature of the Catholic Church in Scotland and Irish immigration during this period, and thereafter was the critical reason for this expansion. ${ }^{14}$

Throughout the Great Hunger years the number of frantic and wretched refugees fleeing to Scotland gathered pace and in Glasgow there was a corresponding increase in the number of recorded deaths, mostly related to the massive rise in cholera deaths as a result of the Great Hunger influx. ${ }^{15}$ Aligning with the increase in 'Famine' refugees to the greater Glasgow area, articles decrying the influx appeared regularly in the Scottish press, usually blaming the Irish for 'importing typhus fever, corrupting the lower orders of Scotland by setting the most pernicious example of dependency on parochial aid, and of spreading criminality'. ${ }^{16}$ It is unsurprising then that one popular aspect of fear exhibited by the overwhelmingly Protestant majority and institutions related to Catholicism and its "foreign" adherents. Prejudice towards Irish Catholics 
came not only from traditional religious or political foes but was endemic throughout society. ${ }^{17}$

\section{Poverty, Charity and Celtic FC}

The growth of the Catholic faith is a vital component in understanding Celtic's formation and subsequent evolution. As Irish immigration resulted in the re-emergence of Catholicism in Scotland and as Catholic Churches evolved so also did Catholic charities. This further development was also of critical importance to the emergence of Celtic FC.

During, and immediately after the Great Hunger, and despite some advances in the provision of support for the impoverished, the vast majority of Scotland's poor had no welfare safety net. ${ }^{18}$ Many people were frequently unemployed while some of the worst housing in Europe existed in and around Scotland's west-central belt. Notwithstanding Glasgow being well on its way to becoming the shipbuilding capital of the world during the 1880s, with Glasgow's River Clyde producing almost a fifth of the world's shipping output by the time of the First World War, life expectancy in Scotland was forty-five for women and forty-two for men. ${ }^{19}$ Despite its great and growing wealth and colonial status, Glasgow and Scotland contained profound inequalities in relation to education, health, housing, class and employment.

Seeking to address and counter poverty and inequality the Catholic organisation Society of Mary (Marists), came to Glasgow in 1858 and forthwith made a formidable contribution to, amongst other things, the education of poor Irish Catholic children in the East End of the city. ${ }^{20}$ In the decades after many of the worst excesses of An Gorta Mor had subsided, football became a highly popular game throughout Britain, especially for working men who were then acquiring more leisure time. In Glasgow, Irish immigrant Marist teacher Brother Walfrid, and some of his Irish-Catholic compatriots, saw in the development and immediate popularity of soccer an opportunity to raise money to feed poor immigrant Irish Catholics in the east end of the city. ${ }^{21}$ The main purpose in the club's formation was explained in a circular issued in January 1888:

The main object of the club is to supply the East End conferences of the St Vincent de Paul Society with the funds for the maintenance of the 'dinner tables' of our needy children in the missions of St Mary's, Sacred Heart and St Michael's. Many cases of sheer poverty are left unaided through lack of means. It is therefore with this object that we have set afloat the 'Celtic'. ${ }^{22}$ 
Celtic's ethno-religious make-up, along with its early successes on the football field, helped attract crowds to football that had not previously been experienced in Scotland. In 1888 , the first full year of its existence, the club gave over $£ 400$ (a sum worth around $£ 40,000$ in 2018 ) to charity as well as playing matches for charitable events in various parts of the country: the income for which was estimated at $£ 150 .^{23}$ Its regular contribution was $£ 20$ a month to each of the children’s 'dinner tables' of the three East End parishes.

During its early years Celtic's founders also frequently donated to Irish ethnic and political bodies. An Irish nationalist dimension involved in the establishment of Celtic is emphasised by Wilson who notes that although the decision:

to form Celtic Football Club is rightly identified with the needs of Catholic charity in the East End of Glasgow....the early nature of the club, and the direction it pursued, owe at least as much to the influence exercised by the political organisation which spoke for the vast majority of the Irish in Scotland in the 1880 s, the Irish National League. ${ }^{24}$

Although Celtic's founders established a symbol of, and representation for, Irish Catholic migrants in much of Scotland, the club did not exclude on the basis of religion or ethnic or national origin. Moreover, throughout Celtic's history, many of its legendary players, staff and supporters have derived from non-Irish and/or nonCatholic backgrounds. Indeed, the club's most successful (and celebrated) manager Jock Stein - manager of the immortalised Lisbon Lions ${ }^{25}$ - stands out among many Protestant/non-Catholic iconic players and staff, including four of the eleven players that won the European Cup.

Although not a Catholic football club, as some observers inaccurately describe $\mathrm{it}^{26}$, Catholics and Catholicism have been central with regards Celtic's origins, ethos, successes and identities (traditional and modern). Without Catholics, Catholicism and the Catholic Church in Scotland, there would be no Celtic Football Club. This fact is fundamental and pivotal to understanding the club's origins, appeal, evolution, resilience and identities. It is also unique because this is in contrast to virtually all other professional football clubs in Scotland ${ }^{27}$ (and Britain) that have somewhat inevitably reflected the traditionally dominant local, regional and national identities and cultures of the vast majority of the population on the island which were, broadly speaking, products of a (Protestant) church and state combination ${ }^{28}$. Celtic's unique identity contrasted sharply with dominant forms of Scottish and British identities. 


\section{Imagined Scottish-British Community}

In contrasting popular and/or dominant forms of British identity with her own Black, Ghanaian-British identity, Hirsch astutely exclaimed:

The narratives that you see on the television, in film and at the theatre shape nothing less than your sense of your own life, your very perception of yourself. My first exposure to the notion that there were other black people in the world, and that some of them lived in nice houses and had happy marriages, was watching American sitcoms. ${ }^{29}$

An equivalent assertion could be applied to the Irish diaspora in Scotland, who also experience such discrepancy between their own perceptions of their identity and promoted or dominant forms of Britishness. ${ }^{30}$ Aspects of these dominant forms of Britishness can be charted on the annual calendar and are performed and reproduced 'like clockwork'. From the Royal Family's much lauded and publicised Church attendance on the first day of each New Year, through to the Queen's Christmas message on the last week of the year, numerous re-produced imaginings of $a$ British identity exists. In sport specifically, there is 'the Boat Race' representing the country's two elite university teams competing for ancient bragging rights while subtly reinforcing classist conceptions of sport, amateurism and the British establishment. There is also the Derby, the Six Nations, the FA Cup Final, and Wimbledon, all patronised by Royalty and celebrated as 'ours'. Away from the sacred practice of sport, there is Guy Fawks night in November - a celebration of the burning of the Catholic 'traitor' who tried to blow up the Houses of Parliament, followed by Remembrance Sunday, many aspects of which commemorate and celebrate British militarism. Moreover, public statues, paintings and school curricula reveal a British history and identity that is partial, questionable or alien to many people in Britain. ${ }^{31}$ When Scottishness is the prominent identity, this sometimes exudes elements of Britishness and/or Protestantism. In sport for example, the Scotland rugby union team's most celebrated supporter is member of the British royal family, Princess Anne, whose enthusiastic and public singing of the (unofficial) Scottish national anthem Flower of Scotland before Scotland's matches transforms a Scottish rebel song into a harmless folk tune embraced by the British establishment. In poetry, the celebrated poet, Robert Burns - whose $25^{\text {th }}$ of January birthday has historically represented a national day of 'Scottish' celebration - is memorialised annually across the world with Burns Nights which often represent their Scottishness with a "Loyal Toast" to the Queen embedded 
into their order of service. Additionally, the ceremonial opening of the Scottish parliament involves the (Protestant) Church of Scotland centrally involved in "Kirking ${ }^{32}$ of the Parliament". These are in addition to the United Kingdom having a constitutional rule prohibiting Roman Catholics from becoming (unelected) Head of State. Accompanying these particularly narrow signifiers of Britishness (and/or Scottishness) that were (and still are) regularly re-presented by and personified in a series of imagined 'British' ('Scottish') symbolic signs, was an absence, an invisibility, and indeed an antagonism to explicit symbols and imaginings of alternative identities, especially those perceived to challenge or disrupt officially preferred narratives relating to colonialism, starvation and British rule in Ireland.

\section{Celtic FC and Irishness: Scotland's lingering Other?}

Celtic's non-prejudiced and inclusive outlook was in stark contrast to how they perceived others to behave towards their own mainly Irish-Catholic constituency. For many players, supporters and observers identifying with Celtic, a significant aspect around the club and its fans' history, identities and narratives is characterised by having to face experiences broadly perceived as discriminatory, prejudicial and hostile towards Catholicism, Irish ethnicity and Celtic in Scotland. ${ }^{33}$ Such perceptions were born from many years of facing bigotry and prejudice. Celtic's presence and subsequent success in a traditionally Protestant and imperialist country containing significant and defining elements of anti-Catholicism, attracted hostility, antagonism, prejudice and discrimination. In 1896 Celtic and Hibernian were top of the Scottish league prompting a popular Scottish Sport newspaper to note the dominance of two Irish teams, asking where was the Scottish team that could challenge the incomers. ${ }^{34}$ While it might not be unexpected in sporting terms to seek a 'Scottish' team to challenge the perceived 'outsiders', a logical assessment of contemporary events would be justified in suspecting prejudice was one motivating factor for such Othering of the 'Irish'. Celtic's Other status endures in the prejudicial discourses of the $20^{\text {th }}-21^{\text {st }}$ centuries concerning the Irishness and Catholicism of the club and its supporters in Scotland. ${ }^{35}$

Up till the 1990s Scotland was still a place where there was a widely-held perception - firmly rooted in historical events - that Catholics (especially of Irish origin) could only go so far in numerous parts of Scotland's economic, social and political life. This was reality (in part at least) in banking, media and football up to and including the 1980s.$^{36}$ Rangers' non-Catholic employment practice that ended in 1989 
was merely one element. Rangers' policy represented more than a petty prejudiced football rivalry point scoring exercise damaging as that was. It encapsulated, legitimised and reproduced, in the 'safety' of sport, the pernicious (and racist) idea that Irish-Catholics were less than equal.

Partly reflecting an inter-war anti-Catholic and anti-Irish Institutional Church of Scotland (Protestant) campaign, in 1952 the Scottish Football Association ordered Celtic to take down the Irish national flag from its stadium or be suspended from football. ${ }^{37}$ Although the confrontation with Celtic and its supporters' ethnic Irishness eventually waned and the Irish flag survived at Celtic Park, the emblem's presence continues to be the subject of hostility in Scotland. ${ }^{38}$ In the contemporary sports arena in Scotland, opposing fans sometimes sing to Celtic supporters, 'Can you sing a Scottish song?' or boo Celtic's supporters' singing of the Irish ballad 'Fields of Athenry': sometimes singing 'Flower of Scotland' as a retort while Celtic's associations with Catholicism has also been targeted and problematised. ${ }^{39}$

Othering takes various forms. In $21^{\text {st }}$ century Scotland it is less likely to be employment-related or structurally embedded prejudice. MacMillan illustrates what we contend to be an often overlooked form of Othering of the Irish diaspora in Scotland. He highlights that Scotland's multi-generational Irish community remains 'absent from socio-economic, political and cultural research, novels, histories and media stories'. In many spaces where one might expect historical or contemporary references regarding Scotland's largest minority, dominant narratives remain silent on, for instance, An Gorta Mor or the Irish Rebellion of 1916 and their relevance and consequences for Scotland (and Britain). ${ }^{40}$ This is especially acute in terms of Scotland's responsibility as part of the major occupying colonial power involved in both situations, and, in the aftermath of An Gorta Mor, in relation to the subsequent mass immigration to Scotland, the consequential revival of the Catholic Church and the emergence of Celtic Football Club. Indeed, such omissions resonate with the somewhat partial recordings and representations of Celtic's European Cup victory in a range of newspapers, documentaries and books.

We argue that structurally prejudiced practices have either ceased or become more difficult to locate, and for some, this has been sufficient to view 'sectarianism' in $21^{\text {st }}$ century Scotland as almost exclusively between a small number of extreme individuals. ${ }^{41}$ However, such analyses miss the important point that acts of so-called 
sectarianism in Scotland are now overwhelmingly subtle and dysconscious rather than explicit and orchestrated.

There are parallels here with other minorities who have experienced being Othered in Britain. For example, Hirsch ${ }^{42}$ acknowledges being Othered by individuals who would be horrified at being branded racist or prejudiced. She illustrates the complexity of Othering by highlighting that despite being British born and raised, as a descendent of Ghana, Britain offered "the painful reminder that home was a place that had surveyed me as alien, questioned me about my background, and expected me to provide explanations". ${ }^{43}$ Revealingly in discussing $21^{\text {st }}$ century Britain, she adds "this country of mine has never allowed me to feel that it is where I belong". ${ }^{44}$ Hirsch laments that this can be partly explained by the powerful and dominant cultural reference points of British identity. Discussing literature, poetry, art and history she laments "[b]ut there were no images in which I saw myself reflected". ${ }^{45}$ Hirsch and the black communities in Britain shared with the Irish diaspora in Britain the perception (merited or not) that their cultures, histories, heroes/heroines and ultimately identities were unworthy of recognition, inconsequential and too foreign, alien and in breach of popular or permissible expressions of Britishness.

\section{What do they know of Lisbon 1967 who only Lisbon 1967 know?}

Denying or reducing such histories is a crucial element when assessing the significance and legacy of Lisbon 1967. CLR James famously illustrated the intimate connections between self-identity and an imagined people's "whole past history" when contrasting the differences between the West Indies and England. He insightfully stressed:

West Indians crowding to Tests bring with them the whole past history and future hopes of the islands. English people, for example, have a conception of themselves breathed from birth ... We of the West Indies have none at all, none that we know of. To such people the three W's, Ram and Val wrecking English batting, help to fill a huge gap in their consciousness and in their needs. ${ }^{46}$

The Lisbon Lions did for the Irish diaspora in Scotland what (James suggests) the West Indies cricketers did for West Indians. Where the three W's, Ram and Val helped West Indians fill a huge gap in consciousness and needs - undoubtedly made more powerful by beating England, a significant part of the colonizing nation-state that had arguably contributed to the lack of self-identity James so eloquently lamented - Celtic had Billy McNeil (captain), Tommy Gemmell (goal scorer) and Stevie Chalmers (winning goal 
scorer). The Lisbon Lions enabled a stateless people [of two nations] to celebrate their marginalised and sometimes despised identities, to exclaim to Scotland, Britain and Europe, that they too had a consciousness, a past history and future hopes, and that their identity had value where they were otherwise often marginalised and Othered.

As Maya Angelou ${ }^{47}$ describes, "[T] he ache for home lives in all of us, the safe place where we can go as we are and not be questioned". The cumulative effect of being Othered can, consciously or not, lead to a search for belonging. CLR James showed that for West 'Indians this place was the cricket field. For many of the Irish diaspora in Scotland, this place was (and remains) Celtic Park. This is where their songs and symbols could be experienced, expressed and even celebrated without embarrassment or fear. For every Lord Nelson the 'British' celebrated these Celtic supporters had James Connolly - a Scottish born Irishman, socialist and republican, a leader of the 1916 Irish Rebellion. ${ }^{48}$ Songs remembering 'Famine' and oppression represent many Celtic supporters' identities, more than Loyal Toasts to royalty, the General Assembly of the Church of Scotland, the Battle of Trafalgar, the Queen's message on Christmas Day or which of England's elite Oxbridge universities can row the fastest. ${ }^{49}$

The testimonies of the Irish 2 Project $^{50}$ demonstrates many Irish descended people in Scotland continue to esteem their Irish ethnicity and do so in relation to Celtic $^{51}$. For example, interviewee Monica McKevitt considered that Celtic was "a big part of being Irish..... I think it's because, to me like you're away from Ireland so that kind of holds some of your Irishness to a certain extent". One participant also expressed his diasporic Irishness as closely linked to his support for Celtic. ${ }^{52}$

It's not just the football club of course, it's a lot more.... You know you can express an Irish identity and there's safety at Celtic Park, whereas you wouldn't be able to express it outside [of the Celtic environment].

Another said:

Celtic is our standard bearer in Scotland. They've never been an Irish only or a Catholic only club because that would be wrong. But Celtic is essentially about us - it's our team, our club and our community.....Every time we win a big match it's a celebration for a community. ${ }^{53}$

English born Irish writer and rock star, the Pogues' Shane McGowan, also recognised Celtic's core Irishness when he said that despite not being very interested in soccer, with specific regard to Celtic, they "are the only team I'm interested in apart from the Ireland team". ${ }^{54}$ Ex-Celtic footballer and manager Tommy Burns, considered that 
Celtic footballers had to remember that 'it's more than just a football team they're playing for. They're playing for a cause and a people". ${ }^{55}$ Another Irish 2 Project interviewee made a distinct connection with the joy of Celtic's win in Lisbon, the marginalisation of those of Irish descent in Scotland and the socio-psychological mindset that many of them shared:

Things started changing [then]. I mean when Celtic started hitting the high spots at Lisbon and that, it definitely gave us all a great boost then and we didn't seem to be so much the underdog any longer. ${ }^{56}$

Such discourses are evidence of the common perception that football goes beyond 'mere' sport and in fact, almost certainly finds its lifeblood in the extra-sporting passions and meanings that link it to everyday aspects of life, especially those that are social and invoke community. In this context, and significantly for Celtic and its community of supporters, such comments demonstrate the club's emblematic and symbolic nature as intrinsically linked to the Irishness of the immigrant diaspora in Scottish society. Beyond matters of faith, for over a century Celtic has been the most significant culturally symbolic champion of the Irish Catholic diasporic community in Scotland. Over several generations Celtic has in particular become part of a shared biography for many thousands of Irish descended Celtic supporters, a part of their selfdefinition. Celtic is a conduit and public space for the construction and expression of diasporic Irishness, an iconic football club with a multi-layered hybrid identity reflecting its birth from poverty born from the consequences of imperialism, and its crucial cultural role within the Irish community in Scotland. Celtic is defined by its unique roots, identities, links and associations with Ireland and Catholicism, an underlying charitable ethos as well as being a club open to players, staff and supporters regardless of ethnicity, nationality or religion: this despite the ethnic and religious hostility often faced by the club and its supporters in Scottish life. Traditionally these have been key attributes for Irish-immigrant-descended Catholics while, within a Scottish context, making the club and its fanbase conspicuous as Scotland's renowned cultural, ethnic and sporting Other. Nonetheless, despite facing prejudice and discrimination in sport and wider society, led by a Scottish Protestant manager, by the 1960s and 1970s Celtic had risen to become one of the illustrious teams in world football, acquiring a then world record nine Scottish League Championship titles in succession and winning the European Champions Cup in 1967. 
Lisbon 1967 permitted the Irish in Scotland a moment - indeed, a legacy - to celebrate a widely represented Scottish and British sporting success that was at its core much more than that, because it was also very much theirs. Yet, the fact it was perceived as a Scottish and British success by some observers permitted the Irish diaspora in Scotland to celebrate, in some ways, their win without coding or camouflaging their identity or fear of causing offence.

The ground breaking Beyond a Boundary charted CLR James's alienation in his own country as a result of internalising the coloniser's cultural and structural norms. In contrast, Hirsch's account of being Othered in the country where she was born and raised speaks of the diasporic longing for a 'home' that she has not lived in. For many Irish diaspora in Scotland their experiences are a combination as well as variations of these positions. In common with Hirsch, there is often a longing for their diasporic country (Ireland) accompanied by a feeling of being negatively Othered in their country of birth and residence. In common with James, the Irish diaspora in Scotland face alienation from, and can be opposed by, their coloniser's norms, values and customs. But unlike James's experiences, they live in the coloniser's country. Lisbon 1967 was a moment for the multi-generational Irish in Scotland to feel proud of their diasporic heritage and to live in their Scottish home in ways that permitted them and others to recognise that they also belonged in, and in some fashion to, their country of residence.

\section{Conclusion}

Contemporary Scotland is not a bastion of anti-Irishness or anti-Catholicism and Lisbon 1967 does not exclusively belong to the Irish diaspora community in Scotland. Likewise, Irish diaspora identities are not one-dimensional, universally experienced or easily internalised even by those that strongly esteem their Irish ethnicity in Scotland. Negotiating dual and multiple identities is problematic, sometimes paradoxical, and challenging in ways that are still poorly understood and only occasionally acknowledged. As Hirsch notes in relation to her Otherness, when she first selfidentified as 'black' in her teens her mum asked her how she thought her (white) dad felt at that. This can be seen to capture the essence of negotiating contrasting elements of one's identity even among family members - never mind in the world of employment and general public life, including sport. It involves avoiding causing hurt or misunderstanding by expressing one's Otherness too openly. Furthermore, for many diasporic individuals, such challenges compete with simply being comfortable in one's 
skin (literally and metaphorically). Hirsch observes "many people I know have learned to code their otherness". ${ }^{57}$ This can occur due to a fear of causing offence or it can be simply trying to fit in. ${ }^{58}$ They are always nonetheless, indelibly contoured and conditioned by the very context in which they seek to be maintained, expressed and celebrated.

Yet, despite Lisbon 1967 fostering a new-found confidence for many of the Irish diaspora in Scotland, there remain lingering cultural prejudices requiring recognition and acknowledgment of their existence before they can ever be overcome. For example, at iconic moments in Celtic's history when Irish symbolism has surfaced or been prominent, there remain sections of Scottish society who openly question and problematise this. For example, when Celtic participated in the UEFA Cup Final of 2003 in the Spanish city of Seville, one letter writer to a Scottish newspaper (in common with many other observers at the time), wrote:

I could have sworn the UEFA Cup Final in Seville was between teams from Scotland and Portugal, but judging by the flags in the stadium I think it was actually Ireland against Portugal........ can't imagine what the rest of the world thought as they watched..... This was not a good reflection on our culture and a bad night for Scottish sport. ${ }^{59}$

While preventing such petty prejudices is problematic, permitting such Othering to go unchallenged works to normalise it. Framing Irish symbols as part of the problem of 'sectarianism' in Scotland reveals the dysconscious reality of prejudice that the Irish diaspora in Scotland sometimes still experience. Just as Hirsch proclaimed "the era of racism without racists is the story of my life" 60 , the Irish diaspora in $21^{\text {st }}$ century Scotland could proclaim the era of sectarianism without bigots is the story of their life. As Hirsch further observes in relation to the denial of Black history and identity:

Interwoven into this branding is the idea that we don't see race, that this is a good thing, it represents the ability to transcend prejudice. But this has become part of the problem. It is denial, avoidance and obfuscation. You cannot just paint everyone in the families of the future a pleasant shade of light brown, and expect questions of identity, racial difference and histories of oppression to disappear. ${ }^{61}$

Celtic supporters flying the Irish flag is not the problem. Indeed, the questioning and problematising of Celtic supporters flying the Irish flag is itself a problem as such Othering narratives go unchallenged and are largely accepted as desirable in contesting 'sectarianism'. ${ }^{62}$ Subtle prejudices are built into the very foundations of contemporary 
anti-sectarianism discourses in Scotland revealing a fundamental ontological flaw. The justification appears 'on the surface' to rest on the simplistic notion that difference is bad, that everyone flying the same (presumably Scottish or British) flag is how to tackle 'sectarianism'. It is not ethno-religious prejudice, hostility and discrimination that are being popularly referred to through dominant 'sectarian' discourses in Scotland. It is having a noticeable religious/ethnic identity different from that of the majority (past or/and present): Irishness and Catholic identities are frequently viewed, constructed and represented as problematic. Such frameworks work to reduce or deny difference, significantly too, overlooking the history of oppression, starvation, colonialism and struggle in and between Ireland and Scotland/Britain.

Hirsch's following comment could be written for the multi-generational Irish diaspora in Scotland

one of the side effects of a society that claims not to see race is that anyone whose appearance is an excessive reminder of difference needs to conform. Failing to do so is frequently perceived as an act of radical politics. ${ }^{63}$

Whitewashing diasporic identities - camouflaged as tackling religious hate - and seeking uniformity is not a solution to prejudice. These identities do matter, and them mattering is natural, normal and not something we should seek to prevent - especially not in the name of anti-bigotry. Moreover, the shared history, struggle and identity of the Irish diaspora in Scotland assume heightened radicality partly because they have been silenced, censored and sectarianised for so long in Scotland and Britain.

Just as CLR James ${ }^{64}$ cautioned against examining the remarkable cricketing feats of England's WG Grace and the West Indies' Wilton St Hill, unless viewed in relation to the social history of England and the West Indies respectively, Celtic's European Cup victory loses its more meaningful significance unless examined in close relation to the history of Scotland's Irish diaspora. To paraphrase James, when Celtic triumphed as European champions on what other occasion was there ever - among the Irish diaspora in Scotland at least - such enthusiasm, such an unforced sense of community, of the universal merged in a team of eleven (local) sportsmen or sportswomen? Celtic's 1967 victory is not merely the story of a great sporting accomplishment - as extraordinary as it was and remains - it was a landmark moment in the social and cultural history of a country (Scotland) and a people (Irish-Catholic diaspora) within that country. ${ }^{65}$ 


\section{References}

Anderson, Benedict. Imagined Communities: Reflections on the Origins and Spread of Nationalism. London: Verso, 1983/2016.

Bradley, Joseph, M. 1995, Ethnic and Religious Identity in Modern Scotland: Culture, Politics and Football. Avebury: Aldershot, 1995.

Bradley, Joseph, M. Celtic Minded: Essays on Religion, Politics, Society, Identity and Football. Argyll: Argyll Publishing, 2004.

Bradley, Joseph, M. Celtic Minded 2: Essays on Celtic Football Culture and Identity. Argyll: Argyll Publishing, 2006.

Bradley, Joseph, M. The Gaelic Athletic Association and Irishness in Scotland: History, Ethnicity, Politics, Culture and Identity. Argyll: Argyll Publishing, 2007.

Bradley, Joseph, M. Celtic Minded 3: Essays on Celtic Football Culture and Identity. Argyll: Argyll Publishing, 2009.

Bruce, Steve and Glendinning, T. 'Sectarianism in the Scottish Labour Market: What the 2011 Census Show’, Scottish Affairs 26, no. 2 (2017): 163-175.

Bruce, Steve and Glendinning, T. and Rosie, Michael. Sectarianism in Scotland. Edinburgh: Edinburgh University Press, 2004.

Burrowes, John. Irish: The Remarkable Saga of a Nation and a City. Edinburgh: Mainstream, 2003.

Campbell, Tom, and Woods, Pat. Celtic Football Club 1887-1986. Edinburgh: Mainstream, 1986.

Colley, Linda. Britons: Forging the Nation, 1707-1837. New Haven: Yale University Press, 1992/1996.

Daily Star, letters, 26 May 2003.

Devine, Tom, M. 'The Great Irish Famine and Scottish History' in New Perspectives on The Irish in Scotland, ed. M. Mitchell, 27. Edinburgh: John Donald, 2008.

Docherty, Gerry, and Thomson, Phil. 100 Years of Hibs 1875/1975, Edinburgh: John Donald, 1975.

Finn, Gerry P.T. 'Racism, Religion and Social Prejudice: Irish Catholic Clubs, Soccer and Scottish Society. II Social Identities and Conspiracy Theories'. The International Journal of the History of Sport 8, no. 3 (1991): 370-397.

Finn, Gerry P.T. 'Racism, Religion and Social Prejudice: Irish Catholic Clubs, Soccer and Scottish Society. I The Historical Roots of Prejudice.' The International Journal of the History of Sport 8, no. 3 (1991): 72-95. 
Finn, Gerry P.T. 'Faith, Hope and Bigotry: Case Studies of Anti-Catholic Prejudice in Scottish Soccer and Society'. In The Making of the Nation; Ninety-Minute Patriots, ed. Grant Jarvie and Graham Walker, 91-112. Leicester: Leicester University Press, 1994.

Finn, Gerry P.T. 'Sporting Symbols, Sporting Identities: Soccer and Intergroup Conflict in Scotland and Northern Ireland'. In Scotland and Ulster, ed. Ian S. Wood, 33-35. Edinburgh: Mercat Press, 1984.

Flint, John and Kelly, John. Bigotry, Football and Scotland. Edinburgh: Edinburgh University Press, 2013.

Gallagher, Tom. Glasgow the Uneasy Peace. Manchester: Manchester University Press, 1987.

Handley, James, E. 'A History of the Province of the British Isles'. Unpublished Manuscript, 1968.

Hirsch, Afua. British: On Race, Identity and Belonging. London: Jonathan Cape, 2018.

Hobsbawm, Eric. Nations and Nationalism Since 1780: Programme, Myth, Reality. Cambridge: Cambridge University Press, 1990.

Bradley, Joseph., Morgan, Name; Hickman, Name and Walter, Name. Irish 2 Project. Economic and Social Research Council, 2002.

see http://www.anglia.ac.uk/geography/progress/irish2/

James, C.L.R. Beyond a Boundary. London: Stanley Paul and Co: Publisher, 1963.

Kay, Joyce, and Vamplew, Wray. 'Beyond Altruism: British Football and Charity, 1877-1914'. Soccer \& Society 11, no. 3 (2010): 181-97.

Kelly, John. 'Hibernian Football Club: The Forgotten Irish? Sport in Society, 46, no. 4, (2007): 418-435.

Kelly, John. 'Sectarianism' and Scottish Football: Critical Reflections on Dominant Discourse and Press Commentary'. International Review for the Sociology of Sport 46 no. 4 (2011): 418-35.

Kinealy, Christine. A Death-Dealing Famine: The Great Hunger in Ireland. Pluto: London.

Mackay, John, R. The Hibees, The Story of Hibernian Football Club. Edinburgh: John Donald, 1986.

McCann, Fergus. Hampden Park: An Open Letter. The Herald, 12 December 2017.

McBride, Maureen. 'Rethinking Sectarianism: A Qualitative Exploration of the Meanings and Experiences of Football Supporters in the West of Scotland.' Unpublished PhD Thesis, University of Glasgow, 2018. 
McCaffrey, John. 'Roman Catholics in Scotland in the 19th and 20th centuries'. Records of the Scottish Church History Society, 21, no. 2 (1983): 275-300.

McColl, Graham. The Official Biography of Celtic: If You Know The History, London: Headline Book Publishing, 2008.

McNee, Gerry. The Story of Celtic: An Official History 1888-1978, London: Stanley Paul, 1978.

Murray, Bill. The Old Firm: Sectarianism, Sport and Society in Scotland. Edinburgh: Mainstream, 1984.

Neal, Frank. Black 47, Britain and the Famine Irish, Basingstoke: MacMillan, 1997.

Peebles, Ian. Celtic Triumphant, London: Sportsman's Book Club, 1968.

Purdon, Richard. The Rogue from the Pogues, Scotland on Sunday, 5 October 2003.

Scotland on Sunday, Sports letters, 24 March 2002.

Wilson, Brian. Celtic: A Century with Honour, Glasgow: Harper Collins, 1988.

\footnotetext{
${ }^{1}$ There is an argument for one player (Jim Craig) being described as coming from a middle-class family. Either interpretation makes little difference to the general point.

${ }^{2}$ McNee, Celtic History, 24.

${ }^{3}$ It was a Holy Day of Obligation in the Catholic calendar

${ }^{4}$ McColl, Celtic: If You Know The History.

${ }^{5}$ Campbell and Woods, Celtic Football Club: One Hundred Years Centenary Celebration.

${ }^{6}$ Peebles, Celtic Triumphant.

${ }^{7}$ Ibid, Page. JB

${ }^{8}$ In much football discourse in Scotland, Scotland's great rivals England are often represented as being arrogant and over-expectant. Reproducing the imagined humble, non-expectant 'Scots' for a Scottish readership gives more power to both inter-connected and compounding national stereotypes.

${ }^{9}$ Peebles, Celtic Triumphant, Page. JB

${ }^{10}$ James, Beyond a Boundary, 233.

${ }^{11}$ See Benedict Anderson's Imagined Communities.

12“The Great Starvation”, “The Irish Famine”, "The Potato Famine”, “The Great Hunger”, “An Gorta Mor" are all used to describe these events from 1845-1852 when millions of Irish starved. Language here is both political and powerful. Famine implies that the death and destruction resulted from lack of food caused by crop failure (potato blight) when it was the (mis)management and commodification of ample food resources that resulted in death and destruction (see Kinealy)

13 Bradley, Ethnic and Religious Identity in Modern Scotland, 145. In 1755 the government commissioned Webster (previously Moderator of the General Assembly of the Church of Scotland) to obtain data for the first census of Scotland.

${ }^{14}$ McCaffrey, Roman Catholics in Scotland in the 19th and 20th Centuries.

${ }^{15}$ Neal, Black 47, Britain and the Famine Irish, 80.

${ }^{16}$ Devine, The Great Irish Famine and Scottish History, 27.

${ }^{17}$ In 1847, the anti-Catholic journal, The Witness, associated Roman Catholicism with dependence and indigence, and Protestantism with vitality and progress, 'a widely-held Victorian nostrum'. See Gallagher, Glasgow the Uneasy Peace, 16.

${ }^{18}$ The Welfare State, introduced in 1945, sought to offer some protection from the state to citizens who found themselves impoverished.
} 
${ }^{19}$ Burrowes, Irish: The Remarkable Saga of a Nation and a City.

${ }^{20}$ Handley, A History of the Province of the British Isles, 43.

${ }^{21}$ Wilson, Celtic: A Century with Honour, 1-17.

${ }^{22}$ Ibid.

${ }^{23}$ Kay and Vamplew, Beyond Altruism: British Football and Charity, 1877-1914.

${ }^{24}$ Wilson, Celtic: A Century with Honour.

${ }^{25}$ Stein was voted by the Celtic support to be the greatest ever Celt.

${ }^{26}$ Murray, The Old Firm: Sectarianism, Sport and Society in Scotland. See also, Gordon Waddell, The Sunday Mail, 23/5/2010. Additionally, when one of us discussed this article with a Scottish born and raised sport-related academic colleague, she expressed surprise to learn that Celtic had "more than a handful" of non-Catholic supporters.

${ }^{27}$ Hibernian FC, formed in Edinburgh in 1875, have some overlapping elements with Celtic in terms of origins. In terms of identity, there is no longer any genuine comparison. See Kelly, Hibernian Football Club: The Forgotten Irish? for a full discussion.

${ }^{28}$ Colley Britons: Forging the Nation, 1707-1837.

${ }^{29}$ Hirsch, British: On Race, Identity and Belonging, 227.

${ }^{30}$ Perhaps the most up-to-date account of this is McBride Rethinking Sectarianism: A Qualitative Exploration of the Meanings and Experiences of Football Supporters in the West of Scotland.

${ }^{31}$ This is also the case, of course, for many of those in Britain who self identify as British.

${ }^{32}$ Kirking originates from Kirk, the word used in Scotland to describe a (Protestant) Church of Scotland Church.

${ }^{33}$ See Bradley, Celtic Minded series.

${ }^{34}$ Mackay, The Hibees, The Story of Hibernian Football Club; Docherty and Thomson, 100 Years of Hibs 1875/1975.

${ }^{35}$ Bradley, Celtic Minded series.

${ }^{36}$ See Kelly, Sectarianism' and Scottish Football: Critical Reflections on Dominant Discourse and Press Commentary.

${ }^{37}$ Wilson, Celtic: A Century with Honour, 94.

${ }^{38}$ Former Celtic chief executive Fergus McCann disclosed that when Celtic hired Scotland's national stadium Hampden Park (in 1994 when Celtic Park was re-developed) that its owners Queen's Park Football Club 'inserted a clause in the lease - a "deal breaker" as their attorney made clear - that forbade "the display of any foreign flag"'. See McCann, 2017. For other examples, see Daily Star, letters, 26 May 2003, Scotland on Sunday, Sports, letters, 24 March 2002.

${ }^{39}$ Kelly, 'Sectarianism' and Scottish Football: Critical Reflections on Dominant Discourse and Press Commentary.

${ }^{40}$ In extreme cases, this has been a purposeful and politically motivated decision. For example, even the mere opinion that Ireland belongs to the Irish was so problematic to the British establishment in those days that Paul McCartney's song "Give Ireland back to the Irish" was banned by the BBC (among other broadcasters). Revealingly, the British establishment insinuated that expressions of support for Irish independence from Britain equated to supporting the (Provisional) IRA.

${ }^{41}$ See Bruce, Glendinning and Rosie, Sectarianism in Scotland; Bruce and Glendinning Sectarianism in the Scottish Labour Market.

${ }^{42}$ Hirsch, British.

${ }^{43}$ Ibid, 4.

${ }^{44}$ Ibid, 32.

${ }^{45}$ Ibid, 35.

46 James, Beyond a Boundary, 233.

${ }^{47}$ Cited in Hirsch, (numberless page preceding the introductory chapter).

${ }^{48}$ Both authors were schooled in different regions of Scotland and neither had any school lesson discuss James Connolly or the Irish Rebellion despite Connolly being born and raised in Edinburgh and the rebellion involving the British state as key protagonists.

${ }^{49}$ Of course this is not to deny that some Celtic supporters have no interest in James Connolly or that some do not have an interest in any of these typically imagined British signifiers.

50 This project was financed by the Government-sponsored Economic and Social Research Council in 2001/02 and essentially looked at questions and issues of identity, focusing on people born in Britain of at least one Irish-born parent or grandparent. Interviewees have been given pseudonyms for the purpose of reporting findings. The work was carried out by Dr J Bradley, Dr S Morgan, Prof M Hickman \& Prof B Walter. For further references see http://www.anglia.ac.uk/geography/progress/irish2/

${ }^{51}$ Also see McBride Rethinking Sectarianism.

${ }^{52}$ Irish 2 Project Scottish based Irish $2^{\text {nd }} \& 3^{\text {rd }}$ generation respondent. 


\footnotetext{
${ }^{53}$ Ibid.

${ }^{54}$ Purdon, The Rogue from the Pogues.

${ }_{55}^{5}$ Bradley, Celtic Minded, 6.

${ }^{56}$ Irish 2 Project Scottish based Irish $2^{\text {nd }}$ and $3^{\text {rd }}$ generation respondent.

${ }^{57}$ Hirsch, 119

${ }^{58}$ An example from one of the authors' own childhood was when he noticed his mother - usually in the company of non-Catholics - begin replacing the word "chapel" with "Church" in keeping with the majority Protestant term for a Christian place of worship.

${ }^{59}$ Joe insert reference

${ }^{60}$ Hirsch, 117.

${ }^{61}$ Hirsch, 156-157 (our emphasis).

${ }^{62}$ See Flint and Kelly Football, Bigotry and Scotland, introduction and conclusion chapters especially.

${ }^{63}$ Hirsch, 50.

${ }^{64}$ James, Beyond a Boundary.

${ }^{65}$ This is not to overlook the significance this event had and continues to have for others beyond the boundary of Scotland, but our focus is confined to those in Scotland.
} 